\title{
GAMBARAN KEPEDULIAN ORANG TUA PADA ANAK PENYANDANG RETARDASI MENTAL
}

\author{
Lailatul Badriyah, Nia Putri Pebrianti, Wulandari \\ Prodi Bimbingan dan Konseling Islam, Institut Agama Islam Negeri Bengkulu \\ Email: lailatulbadriyah@iainbengkulu.ac.id; niaputrifebrianti21@gmail.com; wulandari@gmail.com
}

\begin{abstract}
This study aims to provide a specific and in-depth overview of the conditions or obstacles experienced by individuals with mental retardation as well as forms of caring and the role of parents in the development of children's intelligence. This research was conducted at the end of March to April 2020 using a qualitative approach with the type of case study and the subjects in this study were 2 people. The instrument used to obtain data was the interview method, filling out the Checklist for Problems (DCM), and direct observation. The results of this study explain that subjects who bear mental retardation have the highest problems in the social field and school curriculum adjustments, and the role and care of parents who are devoted to the maximum can help clients to overcome these obstacles and live their daily lives.
\end{abstract}

Keywords: parental role, mental retardation

\begin{abstract}
ABSTRAK
Penelitian ini bertujuan untuk memberikan gambaran secara spesifik dan mendalam mengenai kondisi atau hambatan-hambatan yang dialami individu penyandang retardasi mental serta bentuk kepedulian dan peran orang tua pada pengembangan intelegensi anak. Penelitian ini dilaksanakan akhir Maret hingga April 2020 dengan menggunakan pendekatan kualitatif dengan tipe penelitian studi kasus (cause study) dan subjek pada penelitian ini berjumlah 2 orang. Instrumen yang digunakan untuk memperoleh data adalah metode wawancara, pengisian Daftar Cek Masalah (DCM), serta pengamatan langsung. Hasil pada penelitian ini menjelaskan bahwa subjek yang menyandang retardasi mental memiliki permasalahan tertinggi pada bidang sosial dan penyesuaian kurikulum sekolah, dan peran serta kepedulian orang tua yang dicurahkan secara maksimal mampu membantu subjek untuk mengatasi hambatan tersebut serta menjalani kehidupan sehari-harinya.
\end{abstract}

Kata kunci: peran orang tua, retardasi mental

\section{PENDAHULUAN}

Menurut data survei Sosial Ekonomi Nasional (SUSENAS) tahun 2012 tentang penyandang disabilitas di Indonesia adalah sebesar 2,45\% atau sekitar 6. 515.500 yang termasuk di dalamnya penyandang retardasi mental. Sedangkan berdasarkan data pokok Sekolah Luar Biasa diseluruh Indonesia tahun 2009 dalam Kemenkes RI berdasarkan kelompok usia sekolah jumlah penduduk di
Indonesia yang menyandang keterbelakangan mental adalah 62. 011 orang. Dengan perbandingan $60 \%$ diderita anak laki-laki dan $40 \%$ diderita anak perempuan, dari jumlah tersebut anak yang menderita retardasi mental sangat berat sebanyak $2,5 \%$, anak retardasi mental berat sebanyak 2,8\%, dan anak retardasi mental ringan sebanyak $3,5 \%$ serta sisanya disebut 
sebagai anak dungu (Kementerian

Kesehatan, 2014)

Retardasi mental merupakan suatu keadaan perkembangan mental yang terhenti atau tidak lengkap yang sering terjadi pada anak, terutama ditandai oleh adanya gangguan selama masa perkembangan, sehingga berpengaruh pada tingkat kecerdasan secara menyeluruh, misalnya kemampuan kognitif, bahasa, motorik dan sosial. Anak retardasi mental memperlihatkan fungsi intelektual dan kemampuan dalam perilaku adaptif di bawah usianya sehingga anak yang mengalami retardasi mental kurang mampu mengembangkan keterampilan dan kebiasaan-kebiasaan yang dimiliki anak usianya (Pratiwi, Handayani \& Raharjo, 2017). Individu yang mengalami retardasi mental cenderung memiliki tingkat intelegensi dibawah rata-rata dan pada masa perkembangan akan mengalami gangguan perkembangan mental yang tidak sepenuhnya sehingga ia akan mengalami kesukaran untuk berinteraksi beradaptasi dengan kondisi lingkungan sekolah maupun masyarakat. Keadaan individu yang seperti ini tentu akan sangat membutuhkan kepedulian orang tua baik dalam bentuk bantuan pengajaran sosialnya, maupun bantuan dalam penyesuaian dengan kondisi sekolah sehingga ia akan lebih memperoleh kemudahan dalam menjalani kesehariannya.
Berdasarkan data temuan di lapangan menjelaskan individu dengan RM kerap kali mengalami masalah hubungan sosial yaitu lebih suka menarik diri dan menjadi pendiam dibandingkan harus aktif berinteraksi dengan sekitar, serta permasalahan dalam kurikulum sekolah yang sulit menguasai dan menangkap penjelasan materi pelajaran. Selain itu, kepedulian serta peran orang tua dianggap kurang diberikan yang seharusnya peran orang tua untuk terus mengajarkan anaknya agar mampu menjalani kehidupannya dengan mudah dalam berbagai aspek. Penerimaan diri orang tua menjadi landasan awal dalam menerapkan pola pengasuhan pada anak Retardasi Mental. Khoiri (2012) menjelaskan terlihat perbedaan kepedulian dan kasih sayang orang tua yang tidak menerima anaknya dengan baik dan orang tua yang memiliki penerimaan baik. Orang tua yang menerima cenderung memberikan kasih sayang yang lebih dan terus mengupayakan perkembangan intelegensi anak. Hal serupa dari Rahmadayanti, dkk (2020) menjelaskan dukungan keluarga yang memiliki peran paling penting bagi orang tua dalam mengasuh dan mendidik anak, sehingga memberikan efek positif bagi orang tua untuk menerima dan melatih segala kekurangan pada anaknya sekaligus menyarankan kepada orang tua yang memiliki anak retardasi mental agar meningkatkan kemandirian anak dengan 
membimbing, memberi contoh dan mengarahkan anak dengan benar dalam melakukan kegiatan aktivitas setiap harinya.

Orang tua yang telah menerima secara positif kondisi anak dengan retardasi mental akana serta merta memberikan hal yang terbaik bagi anaknya. Rinaldi \& Retnowati (2018) meneliti tentang program "Mindful Parenting" yang dimana program tersebut mampu meningkatkan kesejahteraan subjektif ibu karena terus berlatih memberikan pengasuhan yang penuh perhatian sehingga hal positif akan terus diberikan pada anak dan akan membuat ibu memberikan perhatian lebih. Lebih luas lagi Utami (2009) menjelaskan bahwa orang tua yang memiliki anak retardasi mental akan mengasuh anaknya dengan pola asuh yang berbeda dan membutuhkan penyesuaian diri yaitu dengan penuh kasih sayang, perhatian, dan memberikan roll model yang baik sehingga hal tersebut akan ditiru anak untuk mengambangkan intelegensinya.

Penelitian ini bertujuan untuk memaparkan bahwa peran orang tua sangat penting untuk mendukung tumbuh kembangnya anak dengan penyandang retardasi mental. Serta penelitian ini diharapkan mampu memberikan kontribusi pemberian edukasi kepada orang tua yang memiliki anak dengan penyandang retardasi mental bahwa kondisi anak tersebut sangat membutuhkan perhatian dan peran orang tuanya untuk terus mendukung dalam mengembangkan intelegensi dan kemampuan bersosialnya, sehingga untuk kedepannya orang tua akan mampu membantu anaknya untuk mengubah apa yang menjadi kekurangannya menjadi suatu potensi yang dapat merubah kehidupan anak menjadi lebih baik di masa yang akan datang.

\section{METODE}

Jenis penelitian ini adalah penelitian kualitatif dengan pendekatan studi kasus. Seorang peneliti menginterpretasi data dengan mendeskripsikan subjek dan latar penelitian, menemukan tema-tema atau kategori, dan akhirnya menginterpretasi maknanya, baik makna secara personal maupun secara teoritis, mengemukakan halhal unik yang ditemukan serta menawarkan pertanyaan-pertanyaan lanjutan (Zuchdi \& Afifah, 2019). Penelitian ini dilakukan pada tanggal 28 Maret-10 April 2020 di rumah kediaman responden. Subjek pada penelitian ini adalah 2 orang dengan penyandang retardasi mental. Selanjutnya ruang lingkup objek penelitian ini adalah bidang pribadi anak atau individu yang mengalami gangguan perkembangan intelegensi dan mental yang menurunkan kemampuan dalam beradaptasi.

Teknik pengambilam data pada penelitian ini menggunakan pemberian Daftar Cek Masalah (DCM), wawancara dan 
pengamatan langsung. Data yang telah terkumpul kemudian dianalisis dengan teknik triangulasi data untuk melihat keabsahan data. Triangulasi data yaitu melakukan pengecekan kembali kebenaran data-data yang telah diperoleh dengan cara melakukan suatu diskusi dengan peneliti lain sebagai bahan pertimbangan yang digunakan untuk menambah wawasan peneliti terhadap permasalahan yang diteliti, selanjutnya peneliti juga melakukan triangulasi teori dengan memberikan perbandingan data yang telah diperoleh dengan teori-teori yang telah dikumpulkan sebagai bentuk penguat atas data yang telah diperoleh.

\section{HASIL DAN PEMBAHASAN}

\section{A. Deskripsi Singkat Subjek}

Beberapa kondisi dari subjek yang dapat peneliti jabarkan dapat dilihat pada tabel di bawah ini:

Tabel 1. Deskripsi Singkat Subjek

\begin{tabular}{ccl}
\hline No & \multicolumn{1}{c}{ Subjek } & \multicolumn{1}{c}{ Deskripsi Singkat } \\
\hline 1 & Nama: Hidayah & Kondisi mental: Akibat terhambatnya perkembangan \\
& Umur: 24 Tahun & mentalnya subjek sering mengalami kesulitan sewaktu \\
& & sekolah dalam proses belajar dan sering tidak naik kelas. \\
& & Subjek juga mengalami kesulitan untuk menyesuaikan diri \\
& & di lingkungan tempat tinggalnya yang membuat subjek \\
& & malu dan jarang berinteraksi dengan orang lain selain \\
& & kedua orang tuanya
\end{tabular}

Kondisi fisik: subjek memiliki kesehatan yang cukup baik dan jarang mengalami sakit, ketika berbicara mata subjek sering melirik kemana-mana, postur tubuh subjek cukup tinggi dan gemuk dengan kulit putih serta rambut ikal berwarna hitam pekat

Kondisi sosial: subjek tinggal sejak kecil bersama orang tua angkat dan tinggal di lingkungan yang baik dan cukup ramah, namun subjek sukar untuk melakukan interaksi dengan orang disekitarnya serta lebih suka menghabiskan waktunya di rumah dan sampai sekarang jika subjek ingin pergi kemana pun harus ditemani oleh ibunya karena subjek merasa tidak berani jika harus pergi sendirian

2 Nama: Wulan Umur: 18 Tahun
Kondisi mental: subjek sangat mengalami kesulitan dalam proses pembelajaran hingga sempat dikeluarkan oleh pihak sekolah karena beberapa kali tidak naik kelas dan kemudian dipindahkan ke SLB oleh orang tuanya namun subjek masih mengalami kesulitan dalam proses pembelajaran

Kondisi fisik: subjek tumbuh dengan kondisi anggota tubuh yang mengalami kekurangan yaitu dibagian mulutnya yang agak miring, kemudian postur tubuh 
subjek kurus dan lumayan tinggi dengan kulit putih dan rambut kriting berwarna hitam. Subjek juga sering mengalami sakit seperti demam, jarang mau berbicara dengan orang lain

Kondisi sosial: subjek tinggal bersama kedua orang tua kandungnya dan tidak banyak melakukan interaksi dengan orang sekitar selain dengan keluarganya di rumah, dan ia juga tidak diperbolehkan berinteraksi dengan tetangga sekitar karena ditakutkan akan terjadi hal yang tidak diinginkan sehingga ia lebih suka berdiam diri di rumah

Dari tabel di atas dapat peneliti simpulkan beberapa permasalahan anak dengan penyandang retardasi mental kondisi fisik, psikis dan sosialnya hampir sama, yaitu ruang lingkup gerak anak yang dibatasi oleh orang tua. Hal tersebut dipicu dari orang tua yang melihat kondisi kesehatan anak yang rentan sakit, ketakutan orang tua akan hal-hal yang akan terjadi kepada anaknya apabila dibiarkan terlalu jauh, akhirnya membentuk pribadi anak yang tidak dapat bersosialisasi dengan orang lain.

Hal ini diperkuat dengan hasil wawancara dengan orang terdekat dari subjek. Hasil wawancara dapat dilihat pada tabel di bawah ini:

Tabel 2. Tabulasi Data Hasil Wawancara

\begin{tabular}{lll}
\hline No & \multicolumn{3}{c}{ Jawaban Subjek } & Kata Kunci \\
\hline 1 & "Anak saya ini susah ngerti pelajaran waktu & Mengalami kesulitan belajar dan \\
sekolah dulu jadi PR jarang dikerjakan, kalau & mengerjakan PR semampunya \\
dikerjakan ya semampunya dia aja, saya dan & \\
bapaknya juga gak ngerti jadi gak bisa bantu apa- & \\
apa, dia juga orangnya pendiem jarang keluar & \\
rumah main ke tetangga" & & \\
"Anak saya dulu pas sekolah sering tidak naik kelas & Mengalami kesulitan ketika \\
jadi sekolah mengeluarkannya, terus saya & belajar \\
masukkan dia ke SLB namun saya lihat masih juga & \\
dia mengalami kesulitan. Saya juga melarang dia & \\
main dengan temannya karena takut kalau nanti & \\
ada apa-apa dengannya karena dia gak kayak & \\
temennya yang lain" & Sejak kecil subjek sudah \\
\hline "Sejak saya kecil si anak saya sudah kayak gitu" & mengalami gangguan akibat \\
& & keterbelakangan mental \\
\hline & Setelah kelas 2 SD dia tidak naik kelas dan justru & gangguan \\
adeknya yang naik kelas duluan, dia sering tidak & \\
naik kelas itulah setelah keluar sekolah saya & \\
menyekolahkannya di SLB", & \\
\hline
\end{tabular}




\begin{tabular}{|c|c|c|}
\hline 3 & $\begin{array}{l}\text { "Kalau saya dengan bapak sebetulnya jarang } \\
\text { ngurusin sekolah dia karna itu tadi kami juga gak } \\
\text { ngerti, tapi kami berusaha nurutin apa mau dia } \\
\text { biar dia senang" }\end{array}$ & $\begin{array}{l}\text { Kurang perhatian orang tua pada } \\
\text { proses pembelajaran }\end{array}$ \\
\hline & $\begin{array}{l}\text { "Saya sangat memperhatikan anak saya, saya } \\
\text { berusaha membantu dia biar tidak kayak gitu lagi" }\end{array}$ & $\begin{array}{l}\text { Mendapatkan perhatian yang } \\
\text { cukup namun subjek masih } \\
\text { belum memberikan kemajuan }\end{array}$ \\
\hline 4 & $\begin{array}{l}\text { "Saya kadang suka nyuruh dia belajar ke temennya } \\
\text { dekat rumah ini, tapi karna emang dianya yang } \\
\text { pemalu jadi gak mau" }\end{array}$ & $\begin{array}{l}\text { Orang tua mendukung proses } \\
\text { belajar }\end{array}$ \\
\hline & $\begin{array}{l}\text { "Saya sebagai orang tua ya itu tadi saya berusaha } \\
\text { memasukkan anak saya ke SLB tujuannya si supaya } \\
\text { anak saya mampu untuk belajar karena di sekolah } \\
\text { umum dia susah belajarnya, saya juga sering } \\
\text { membawa ia berobat karena sering sakit" }\end{array}$ & $\begin{array}{l}\text { Subjek sering sakit dan } \\
\text { dipindahkan ke SLB untuk } \\
\text { membantu proses belajar }\end{array}$ \\
\hline 5 & "Jarang dia main sama temennya" & Subjek jarang bermain \\
\hline & $\begin{array}{l}\text { "Anak saya ini suka berdiam diri dan jarang mau } \\
\text { ngomong dengan orang lain selain saya, adek dan } \\
\text { bapaknya, dan saya juga terkadang melarang anak } \\
\text { saya main karena takut kalau ada apa-apa sama } \\
\text { dia jadi bisa dibilang sosial anak saya sangat } \\
\text { kurang" }\end{array}$ & $\begin{array}{l}\text { Subjek jarang mau berbicara } \\
\text { dengan orang lain dan berdiam } \\
\text { diri di rumah }\end{array}$ \\
\hline 6 & $\begin{array}{l}\text { "Anak saya sehat dan jarang sakit, makan juga } \\
\text { teratur" }\end{array}$ & Aspek kesehatan subjek baik \\
\hline & $\begin{array}{l}\text { "Kalau Wulan ini kadang sering sakit dan kadang } \\
\text { makannya juga susah, itulah badannya kurus" }\end{array}$ & $\begin{array}{l}\text { Aspek kesehatan subjek sering } \\
\text { terganggu }\end{array}$ \\
\hline 7 & $\begin{array}{l}\text { "Ya pengennya anak saya bisa kayak temennya, } \\
\text { karena kadang tetangga juga sering bilang kenapa } \\
\text { Dayah di rumah terus gak keluar-keluar" }\end{array}$ & $\begin{array}{l}\text { Ada harapan kesembuhan untuk } \\
\text { subjek }\end{array}$ \\
\hline & $\begin{array}{l}\text { "Harapan saya buat anak saya dia cepat sembuh } \\
\text { jadi bisa lebih berani" }\end{array}$ & \\
\hline
\end{tabular}

Dari tabel di atas dapat disimpulkan bahwa masalah kesulitan belajar tidak dapat diatasi karena orang tua juga tidak memahami materi yang diajarkan. Beberapa orang tua memasukkan anaknya ke SLB untuk dapat membantu proses pengajaran, akan tetapi ketika di rumah pelajaran tersebut tidak di ulangi, jadi proses yang di dapat kurang maksimal. Terlihat pula bahwa orang tua lebih fokus kepada kesehatan anak daripada kondisi belajara anak. Berikut akan ditampilakan grafik daftar cek masalah (DCM) yang peneliti ambil dari oran tua subjek. 


\section{Gambar 1. Grafik Hasil Daftar Cek Masalah}

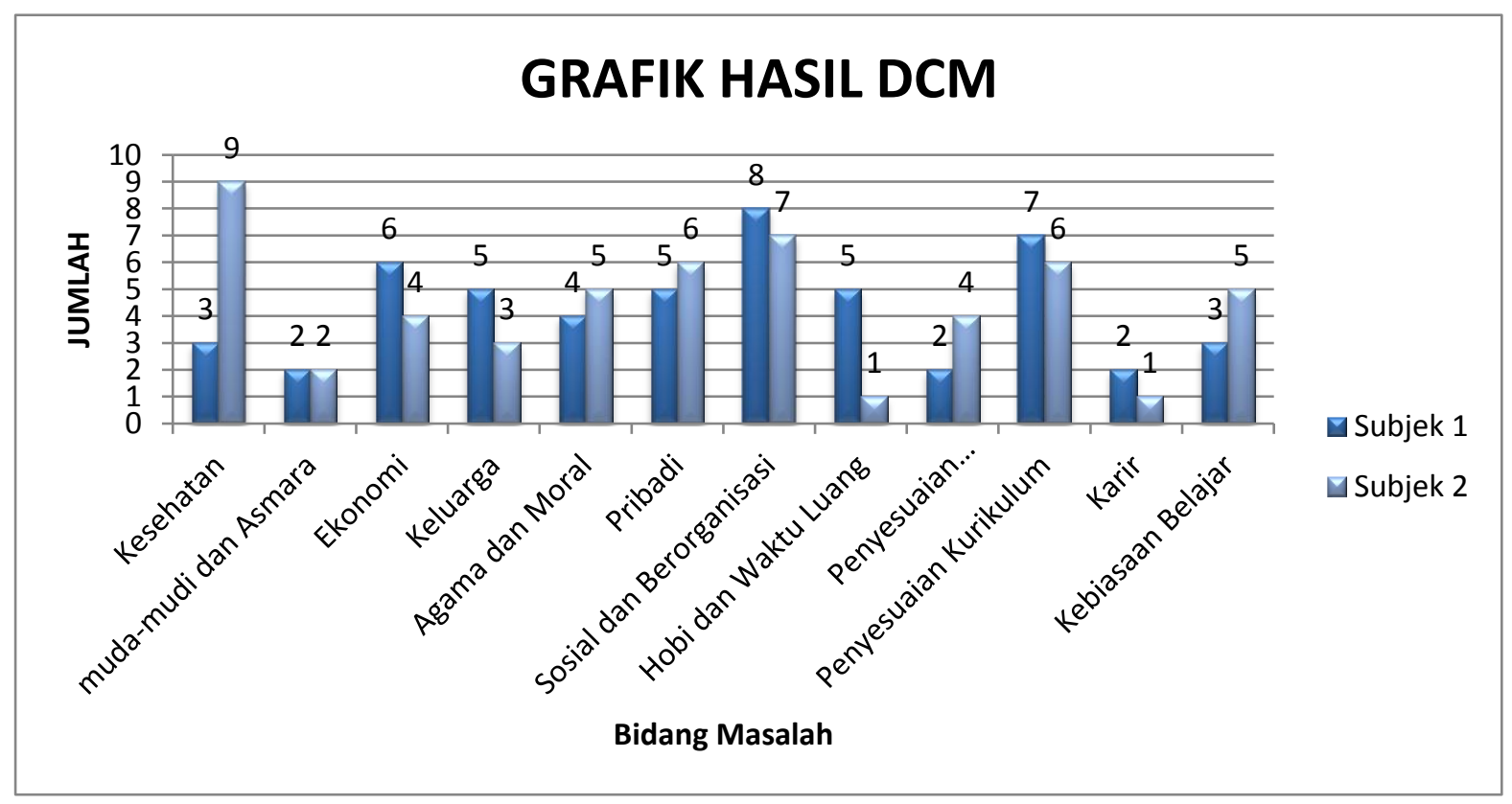

Berdasarkan grafik di atas dapat disimpulkan bagian permasalahan tertinggi terletak pada aspek kesehatan, sosial dan kurikulum. Subjek sangat rentan sakit sehingga orang tua memberikan perhatian lebih dengan pengobatan. Efek dari seringnya anak sakit mengakibatkan pula masalah sosial di masyarakat, anak jarang bergaul dengan tetangga disekitar rumahnya, membentuk pribadi pemalu dan rasa rendah diri karena kekurangan dalam dirinya. kesulitan-kesulitan yang dialami subjek dalam kesehariannya adalah sulitnya menjalin interaksi dengan orang sekitar yang menyebabkan subjek merasa lebih nyaman untuk menjalani kehidupannya sendiri di rumah. Ia akan sukar bermain dalam kelompok karena kebiasaan yang ia jalani sejak kecil yang sudah menutup diri karena rasa malu dan ketidakpercayaan diri yang cukup besar sebagai akibat kurangnya pembiasaan orang tua untuk mengajak anaknya berinteraksi dengan orang disekitar dan justru lebih bangga ketika sang anak mampu membantu semua pekerjaan rumah. Menurut Kusumaningrum (2014) peran orang tua yang membiasakan anak untuk ikut bersosial seperti menemani ibunya berkunjung ke rumah tetangga atau bahkan meminta anak untuk berbelanja ke warung tetangga akan memberikan efek yang sangat besar pada perkembangan sosialnya.

\section{PENUTUP}

Berdasarkan pembahasan yang telah dipaparkan di atas maka dapat disimpulkan bahwa individu yang menyandang retardasi mental atau keterbelakangan mental mengalami beberapa hambatan pada perkembangan intelegensi dan mentalnya. 
Hambatan pada aspek intelegensi sendiri berupa kesulitan yang dialami subjek pada proses belajar sewaktu sekolah yang mengakibatkan tidak naik kelas beberapa kali, sedangkan hambatan pada perkembangan mental berupa keterbatasan untuk melakukan adaptasi atau penyesuaian diri di lingkungan sosialnya yang sukar untuk bersosial dan melakukan interaksi dengan teman maupun orang sekitarnya. Subjek hanya sering melakukan interaksi dengan keluarganya saja dan lebih banyak berdiam diri serta menghabiskan waktunya di rumah.

Selain itu berdasarkan hasil wawancara dan data hasil pengisian Daftar Cek Masalah (DCM) yang telah dilakukan oleh subjek diperoleh beberapa data bahwasanya bidang permasalahan yang menjadi masalah terberat yang dialami subjek adalah pada bidang bersosial dan berorganisasi serta bidang masalah penyesuaian kurikulum sekolah. Kedua bidang tersebut menjadi point tertinggi yang dialami subjek dan juga menjadi pokok permasalahan yang harus diselesaikan oleh orang tua untuk membantu perkembangan kemampuan anaknya. Permasalahan bersosial yang kurang baik akan mampu teratasi dengan peran orang tua untuk melatih dan membiasakan anak melakukan interaksi dengan orang disekitarnya agar proses sosial mampu terbentuk dengan baik. Sedangkan pada aspek pendidikan tentu individu yang mengalami retardasi mental membutuhkan sistem belajar yang lebih khusus dan berbeda dengan anak lain pada umumnya karena individu tersebut memiliki daya tangkap yang lebih lambat.

Gambaran peran sekaligus bentuk kepedulian orang tua yang tercermin pada perhatian yang diberikan secara maksimal dan penuh kesungguhan terbukti mampu memberikan bantuan pada individu yang mengalami retardasi mental untuk terus mengembangkan kemampuan mental dan intelegensinya untuk menjalani kehidupan sehari-hari. Begitupun sebaliknya, kurangnya kepedulian dan peran orang tua untuk terus memperhatikan anak dengan retardasi mental akan memperparah hambatan perkembangan intelegensi dan mentalnya yang berdampak pada kemampuan anak beradaptasi serta mengembangkan potensi. Salah satu solusi permasalah subjek pada aspek sosial dan pendidikannya yaitu dengan memberikan dukungan secara penuh dan kepedulian dalam bentuk perhatian ekstra, karena peran orang tua dalam menyikapi dan membantu permasalahan yang dialami subjek adalah salah satu upaya penting agar subjek mampu untuk terus menjalani kehidupannya. Selain itu, dukungan keluarga atau orang sekitar juga sangat penting diberikan baik pada orang tua maupun pada subjek untuk membantu kemudahan subjek menjalani kehidupan sehari-hari. 


\section{DAFTAR PUSTAKA}

Kemenkes RI. (2014). Penyandang disabilitas anak. Infodatin: pusat informasi kementrian kesehatan RI, Diakses dari http://www.kemkes.go.id/resources/ download/pusdatin/infodatin/infoda tin_disabilitas.pdf.

Khoiri, H. (2012). Penerimaan orang tua terhadap anak retardasi mental ditinjau dari kelas sosial. Developmental and Clinical Psychology. Vol. 1, No. 1. h. 9-14.

Kusumaningrum, R.A. (2014). Gambaran orang tua yang memiliki anak retardasi mental dengan perkembangan sosial baik dan buruk di SLB-BC Mitra Amanda Banyudono Boyolali. Skripsi. Surakarta: Universitas Muhammadiyah Surakarta.

Pratiwi, I.C., Handayani O.W.K., dan Raharjo B.B. (2017). Kemampuan kognitif anak retardasi mental berdasarkan status gizi. Public Health Perspective Journal. Vol. 2 No. 1. h. 19-25.
Rahmadayanti, Atmaja N.S., Udiyani B.P., dan Ritna. (2020). Studi fenomenologi pengalaman orang tua dalam memandirikan anak usia (0-18 tahun) dengan retardasi mental sedang Di SLB Negeri Batulicin Kabupaten Tanah Bumbu 2019. Jurnal Keperawatan Suaka Insan, Vol. 5 Edisi I, Juni.

Rinaldi, Rizky M. dan Retnowati S. (2018). Program "Mindful Parenting" untuk meningkatkan kesejahteraan subjektif ibu yang memiliki anak retardasi mental. Gadjah Mada Journal of Professional Psychology, Vol. 2, No. 2: h. 100-115.

Utami, Y.R. (2009). Penyesuaian diri dan pola asuh orang tua yang memiliki anak retardasi mental. Skripsi. Surakarta: Universitas Muhammadiyah Surakarta

Zuchdi, D., \& Afifah, W. (2019). Analisis konten etnografi \& grounded theory dan hermeneutika dalam penelitian. Jakarta: Bumi Aksara. 